\title{
Competition Policy and Democracy in Pakistan
}

\section{Shahid Amjad Chaudhry}

\begin{abstract}
This paper argues that competition policy has focused exclusively on the productive and financial sectors which has consequently seen periods of extreme concentration of assets by the private sector, nationalisation and subsequent privatisation and de-regulation. However, the political momentum generated from the nationalisation moves in industry and finance has resulted in complete government control through nationalisation of the education sector which has had adverse consequences for human resource development. Public administration has also deteriorated as a result of expansion of the nationalised sector and consequent diversion of economic rents to public administrators. The challenges facing the economy are to increase competitiveness and reduce rent seeking through eliminating trade barriers, privatisation and de-regulation in the production, finance and education sectors which are only possible in democratic environments and which reinforce the democratic process itself particularly through human resource development. An important dilemma relates to the infrastructure and energy sectors where issues of privatising natural monopolies and cartels raise questions of institutional capacity in regulating these sectors.
\end{abstract}

Table-I: Pakistan - Review of Competition Policies

\begin{tabular}{|c|c|c|c|c|c|c|}
\hline & $\begin{array}{c}\% \text { of GDP } \\
1992-93\end{array}$ & $\begin{array}{c}\text { Democracy } \\
1947-58\end{array}$ & $\begin{array}{c}\text { Dictatorship } \\
1958-71\end{array}$ & $\begin{array}{c}\text { Democracy } \\
1972-78\end{array}$ & $\begin{array}{c}\text { Dictatorship } \\
1978-88\end{array}$ & $\begin{array}{c}\text { Democracy } \\
1988-95\end{array}$ \\
\hline Agricu & $25 \%$ & entration & Land Reform & Land Reform & Concentration & Trade Lib \\
\hline & $12 \%$ & Comp & Concer & $\begin{array}{l}\text { Selective } \\
\text { Nationalisation }\end{array}$ & Concen & Trade Lib \\
\hline $\begin{array}{l}\text { Finance \& } \\
\text { Insurance }\end{array}$ & $03 \%$ & Competition & Concentration & $\begin{array}{l}\text { Total } \\
\text { Nationalisation }\end{array}$ & State Owned & \\
\hline Education & $03 \%$ & Competition & Competition & $\begin{array}{l}\text { Total } \\
\text { Nationalisation }\end{array}$ & State Owned & $\begin{array}{l}\text { State } \\
\text { Owned }\end{array}$ \\
\hline Public Adm. & $08 \%$ & Competition & Competition & Politicised & & Politicised \\
\hline Electricity & $03 \%$ & Competition & State Owned & State Owned & State Owned & $\begin{array}{l}\text { State } \\
\text { Owned }\end{array}$ \\
\hline $\begin{array}{l}\text { Gas } \\
\text { Transport \& } \\
\text { Comm. }\end{array}$ & $\begin{array}{l}01 \% \\
0.1 \%\end{array}$ & Carte1 & Cartel & Cartel & Cartel & Cartel \\
\hline Infrastructure & $10 \%$ & State Owned & State Owned & State Owned & State Owned & \\
\hline
\end{tabular}

Paper presented at a symposium on "Markets and Democracy" at Vrije University, Amsterdam on September 28, 1995. 


\section{Introduction}

Pakistan has had a chequered history alternating between roughly equal periods of democratic government and military dictatorship over the past almost 50 years of its existence as an independent country. Five historical perspectives are important from the point of view of the analyses at hand:

(i) The first democratic period 1947-58 was a period of weak democratic but liberal governments.

(ii) The first military dictatorship (F.M. Ayub Khan) 1958-68 was largely liberal and focused on reducing concentration in agricultural land holdings while allowing concentration in large scale industry and finance to increase in protected democratic markets. This the second successor military government of Gen. Yahya Khan tried to correct by creating a Monopoly Control Authority but was overtaken by events in 1971 in East Pakistan.

(iii) The second democratic period (Mr. Zulfiqar Bhutto) 1972-1977 saw wide - spread nationalisations not only in industry and finance but also in education, as we1l as land reform - reflecting a populist anticoncentration platform and the pro-public sector philosophy of the time;

(iv) The third military dictatorship (Gen. Zia-ul-Haq) 1977-1988 saw a strengthening of concentration both in the nationalised public sector and the private industrial and agricultural sector; and

(v) The current democratic period (1988-to date) has seen unprecedented liberalisation and de-regulation, yet many sectors still remain to be deregulated and exposed to competition.

\section{Competition Policy in the Agricultural Sector}

The first sector on which competition policy focused ten years after the creation of Pakistan in 1947 was the agriculture sector in which large feudal holdings (many in excess of tens of thousands of acres) dominated. Of the total farm area of 45-50 million acres, 12-15 per cent officially and about 20-30 per cent unofficially was owned and cultivated by about 6000 big landlords during the first democratic period of 1947-5 8 and these land-owners soon began to exercise political supremacy in the country. 
Table-II: Pakistan - Concentration of Assets in the Agricultural Sector

\begin{tabular}{|c|c|c|c|c|c|}
\hline & $\begin{array}{c}\text { Democracy } \\
1947-58\end{array}$ & $\begin{array}{c}\text { Dictatorship } \\
1958-71\end{array}$ & $\begin{array}{c}\text { Democracy } \\
1972-78\end{array}$ & $\begin{array}{c}\text { Dictatorship } \\
1978-88\end{array}$ & $\begin{array}{c}\text { Democracy } \\
1988-95\end{array}$ \\
\hline $\begin{array}{l}\text { Agriculture } \\
\text { Growth rates }\end{array}$ & $2.4 \%$ & $3.9 \%$ & $2.2 \%$ & $3.9 \%$ & \\
\hline $\begin{array}{l}\text { Agriculture } \\
\text { Policy }\end{array}$ & Concentration & Land Reform & Land Reform & Concentration & Trade Lib \\
\hline $\begin{array}{l}\text { Gini } \\
\text { Coefficients of } \\
\text { operated areas }\end{array}$ & & 0.5137 & 0.5177 & 0.5353 & 0.5847 \\
\hline $\begin{array}{l}\text { Big Farms/ } \\
\text { Ceiling (acres) }\end{array}$ & None & 500 & 150 & 150 & 150 \\
\hline $\begin{array}{l}\text { Acreage (Mn } \\
\text { acres) }\end{array}$ & 7.5 & 7.7 & 4.5 & 4.0 & 4.8 \\
\hline Number & 6061 & 5904 & 16163 & 14031 & 15471 \\
\hline
\end{tabular}

Source: The Pakistan Development Review, Spring 1974 and Winter 1993. Data are for 1948, 1959, 1970, 1980 and 1991 respectively.

Both the first military dictatorship and Mr. Bhutto's democratic government elected on a populist anti-big industrialist, anti feudal platform cut down agricultural land holdings. A great degree of reduction of concentration in landholdings was achieved although the 1972 legal ceiling of 150 acres is alternatively measured in Produce Index Units which can increase it to about 350 acres. Lately there has again been an increase in average size of farm area in large holdings to 310 acres in 1991 from 286 acres in 1980. However, while farms of thousands of acres still exist (held in names of family members and retainers), unlike earlier times there is no serious demand for further land reform. The current democratic government of Ms. Bhutto with its deep roots in the agricultural sector received a recommendation from (its) Prime Minister's Task Force on Agriculture to allow "Corporate agriculture" without area limits. This may indicate future direction of political policy actions.

With regard to sub-sector and crop specific competition policies the sector has received largely negative effective protection (with the possible exception of the live-stock sector). Limited price support programme (all below international prices) are in place for a few crops. There are trade restrictions on exports of foodstuff but competition policies in the current democratic environment are focusing more on freer trade in agriculture. An important policy action being considered is to price irrigation water more realistically and distribute it through Area Water Boards. Since access to cheap water resources is an integral part of the big farmer/feudal syndrome, if implemented this will greatly increase competition in the agricultural sector. 


\section{Competition Policy in Industry and Finance:}

Whilst the first military dictatorship (1958-1968) focused on land reform (reflecting its largely urban ideology and power base) it encouraged concentration in the industrial and finance sectors. By the end of 1970, eighteen industrial groups (Dr. Mahbub-u1-Haq's 22 families) controlled an overwhelming dominant share of the country's industrial assets, banks and insurance companies. The subsequent democratic government's (Mr. Z.A. Bhutto) reaction was populist and state oriented. Major industrial sectors (steel, petroleum chemicals, cement, vegetable oils) were nationalised as were all banks and insurance companies. There followed a period of industrial stagnation which recovered in the following dictatorship period as private industrial and commerce houses rebuilt themselves under military patronage.

Table-III: Pakistan: Concentration of Assets in the Industrial and Finance Sector

\begin{tabular}{|c|c|c|c|c|c|}
\hline & $\begin{array}{l}\text { Democracy } \\
1947-58\end{array}$ & $\begin{array}{c}\text { Dictatorship } \\
1958-71\end{array}$ & $\begin{array}{c}\text { Democrac } \\
y \\
1972-78\end{array}$ & $\begin{array}{c}\text { Dictatorship } \\
1978-88\end{array}$ & $\begin{array}{c}\text { Democracy } \\
1988-95\end{array}$ \\
\hline $\begin{array}{l}\text { Industrial growth } \\
\text { rates(LS) }\end{array}$ & $18 \%$ & $10.8 \%$ & $3.7 \%$ & $9.0 \%$ & $4.8 \%$ \\
\hline Industrial Policy & $\begin{array}{c}\text { Competitio } \\
\mathrm{n}\end{array}$ & Concentration & $\begin{array}{c}\text { Selective } \\
\text { Nationalisa } \\
\text {-tion }\end{array}$ & Concentration & Trade Lib \\
\hline $\begin{array}{l}\text { Finance Sector } \\
\text { Policies }\end{array}$ & $\begin{array}{c}\text { Competitio } \\
\mathrm{n}\end{array}$ & Concentration & $\begin{array}{c}\text { Total } \\
\text { Nationalisa } \\
\text {-tion }\end{array}$ & State Owned & $\begin{array}{c}\text { Competitio } \\
\mathrm{n}\end{array}$ \\
\hline $\begin{array}{l}\text { Number of } \\
\text { "Monopoly Houses" }\end{array}$ & & $18 \%$ & & & $38 \%$ \\
\hline $\begin{array}{l}\text { Control of Karachi } \\
\text { Stock Exchange } \\
\text { Assets }\end{array}$ & & $60 \%$ & & & $46 \%$ \\
\hline $\begin{array}{l}\text { Control of all Assets } \\
\text { in Large Scale } \\
\text { Industry }\end{array}$ & & $35 \%$ & & & $\begin{array}{c}\text { Less than } \\
20 \%\end{array}$ \\
\hline $\begin{array}{l}\text { Control of Banking } \\
\text { Assets }\end{array}$ & & $51 \%$ & & & $\begin{array}{c}\text { Less than } \\
10 \%\end{array}$ \\
\hline $\begin{array}{l}\text { Control of Insurance } \\
\text { Assets }\end{array}$ & & $50 \%$ & & & $\begin{array}{c}\text { Less than } \\
10 \%\end{array}$ \\
\hline
\end{tabular}

Source: For 1970 "Private Industrial Investment in Pakistan", R. Amjad for 1992, Lahore School estimates.

The recent democratic governments have followed a patter of deregulation and privatisation of both state owned industry and financial and banking sectors. While industrial concentration is again on the rise, with 38 
local industrial groups now controlling almost half the assets listed on the Karachi Stock Exchange (book value), trade policy in the form of reduced tariffs (now down to about 65 per cent from about 120 per cent in the early 1980;s) is being used to reduced economic rents. Although recently the industrial lobby delayed the phased reduction in tariffs agreed to with the IMF. The banking and insurance sector has been introducing new private institutions which are constraining the rents accruing to the beneficiaries of the state finance sectors and leading to increased efficiency in the financial sectors.

\section{Competition Policy in Education}

Whilst the focus of competition policy was on the agricultural, industrial and financial sectors which suffered from the excessive use of a blunt policy instrument of nationalisations, these sectors proved to be fairly robust in their recovery as more sophisticated competition policies were adopted particularly in the last several years of democratic governments. However, the sector which has suffered the most has been the education sector and the excesses here have not yet been redressed with drastic effects on Pakistan's human resource development.

Table-II: Pakistan - Concentration of Assets in the Agricultural Sector

\begin{tabular}{lccccc}
\hline & $\begin{array}{c}\text { Democracy } \\
\mathbf{1 9 4 7 - 5 8}\end{array}$ & $\begin{array}{c}\text { Dictatorship } \\
\mathbf{1 9 5 8 - 7 1}\end{array}$ & $\begin{array}{c}\text { Democracy } \\
\mathbf{1 9 7 2 - 7 8}\end{array}$ & $\begin{array}{c}\text { Dictatorship } \\
\mathbf{1 9 7 8 - 8 8}\end{array}$ & $\begin{array}{c}\text { Democracy } \\
\mathbf{1 9 8 8 - 9 5}\end{array}$ \\
\hline Pakistan & Competition & Competition & Nationalisa- & State & Competition \\
Education Policy & Public/Private & Public/Private & tion & $\begin{array}{c}\text { Monopoly } \\
\text { Public }\end{array}$ \\
Schools & & & & & \\
Colleges/Universities & Competition & Competition & Nationalisa- & State & State \\
& Public/Private & Public/Private & tion & Monopoly & Monopoly \\
& & & & Public & 98\% Public \\
& & & & & $02 \%$ Private
\end{tabular}

\begin{tabular}{lccc} 
Pakistan & \multicolumn{3}{l}{} \\
(End Decade) & & & \\
Primary School E/R & $30 \%$ & $40 \%$ & $46 \%$ \\
Secondary School E/R & $11 \%$ & $13 \%$ & $21 \%$ \\
Higher Education E/R & $01 \%$ & $04 \%$ & $03 \%$ \\
India & & & \\
Education Policy & & & \\
(End Decade) & Competition & Competition & Competition Competition Competition \\
& Public/Private & Public/Private & Public/Private Public/Private \\
Primary School E/R & $41 \%$ & $73 \%$ & $102 \%$ \\
Secondary School E/R & $23 \%$ & $26 \%$ & $44 \%$ \\
Higher Education E/R & $02 \%$ & $05 \%$ & n.a. \\
\hline
\end{tabular}

Source: Data for Enrollment Rates are for 1960, 1970 and 1992 respectively from the World Development Reports, World Bank.. 
When Pakistan came into existence in 1947 the education sector was deregulated and quality education by public and private institutions (including foreign and local religious and church run institutions) were provided at both school and college levels all over Pakistan - although coverage was understandably fairly thin after a hundred years of colonialism. This situation prevailed in both the first democratic period and the first dictatorship period (which has been characterised as a liberal dictatorship). However, the education sector was engulfed by Bhutto's populist democratic government where the extreme left in his government prevailed in the nationalisation of all private education institutions in the country (except the dozen missionary schools). The biggest single bureaucracy in the country was created (there are more than 400,000 state employed teachers in Punjab alone) and the emphasis shifted in schools, colleges and universities from providing quality education to maximising bureaucratic benefits. This state of affairs continued in the subsequent military dictatorship period where General Zia-ul-Haq fostered a religious agenda on the educational institutions and religious political groups were given effective control over all educational institutions which they exercised to the utmost, particularly in the Universities.

It was almost inevitable therefore that education in Pakistan deteriorated both in qualitative and quantitative terms as the State itself could not mobilise the required resources and even the resources utilised were used inefficiently. All Pakistan's present educational indicators (TableIV) show Pakistani performance in education at roughly half the Indian level despite a real per capita income level twice that of India. The saddest aspect is that the higher education sector in Pakistan, with a very few notable exceptions, has become an intellectual wasteland.

The recent democratic governments have not yet moved to deregulate the education sector and the huge public education bureaucracy. Their political mentors are creating every obstacle to protect their monopoly positions and prevent the creation of private and non-profit (NGO) educational institutions. Despite this, some private educational institutions (1argely at the school level) are surfacing - basing their curricula and degrees on foreign examination authorities. Overall however, the monopolised public sector educational system presents a thoroughly unsatisfactory state of affairs and needs to be corrected. Bangladesh's de-regulated educational sector policies which allow both public and private universities and treat public and private schools and colleges equally without bureaucratic regulation provide an excellent model for Pakistan to follow. 


\section{Competition Policy in Public Administration}

Mr. Zulfiqar Bhutto's pro-public sector policies discussed above created a vast bureaucracy (currently there are 3 million government civil employees plus a million in the Armed Forces) which comprises 36 per cent of the total employed labour force of the country (there are another 14 million self-employed including agricultural workers and 7 million unpaid family labour). This vast bureaucracy (with a very few honourable exceptions) is essentially not living off its government salaries but is the beneficiary of large economic rents accruing in all sectors where the public sector is actively engaged - nationalised and publicly owned financial institutions, nationalised and public sector industry (particularly steel), public infrastructure, nationalised education, civil administration, etc.

Given the above situation it was almost inevitable that all political and military governments starting with Mr. Bhutto (who undertook the nationalisation and monopoly processes in favour of the public sector) have sought to undermine the independence of the bureaucracy and fill positions with their own supporters. While fortunately elements of integrity remain in the selection of the elite bureaucracy through Public Service Commissions, the lower bureaucracy which comprises 95 per cent of total government employment are now subject to political appointments (almost always in relaxation of rules which specify minimum qualifications) and subjected to complex regional/provincial quota restrictions. Many of the current political problems particularly in the urban areas of Karachi where educated youth find public and semi-public employment avenues closed to them (including in the vast public education sector) can be traced to this erosion of merit as a criteria for employment in the public sector.

An appropriate competition policy for the public administration sector would need several components, (i) A fair and competitive selection process for both initial selection and through successive promotions, (ii) Openness in bureaucratic decision making through a "Freedom of Information Act.", and (iii) A pay and incentive structure relating salary to performance. These are not currently being contemplated in the present political environment.

\section{Competition Policy in Infrastructure Sectors}

Pakistan has launched itself on the complex route of privatising the key telecommunications sector to a selected foreign company. Twelve percent of the state-owned telephone monopoly (2.5 million lines) has been sold for $\$ 1$ billion to the general Pakistan public (2\%) and foreign investors $(10 \%)$ in anticipation of a remaining major share disinvested to a foreign 
"strategic" buyer. Similarly, the power authority (WAPDA) with gross revenue in excess of $\$ 3$ million per annum $(30$ per cent of the Pakistan Federal Budget) is also being readied for privatisation.

While WAPDA has announced a power purchase programme from private generators at attractive prices, its monopoly over the sector will remain largely intact even with these "captive" power plants. This Power Authority is particularly inefficient with transmission and line losses (in many cases through theft, aided by employees) at about 25 per cent - which is three times the world average. Both this Authority and PTC are obviously the beneficiaries of monopoly rents. A sensible privatisation programme (including a foreign buyer) would obviously be in order if appropriate regulation could be ensured. Given the state of poor public administration in Pakistan, several questions arise whether regulation would be adequate. In such a situation, an appropriate alternative strategy would be to privatise both the telecommunication and power system in parts, starting with distribution, privatising a large number of companies (both local and foreign) in different regions, cities and other areas grouped within local government boundaries. This has worked very successfully in the de-regulation process of these sectors in the USA.

Another set of competition policies and regulatory issues arise with regard to petroleum import, refining and distribution policies. Pakistan imports roughly two thirds of its petroleum requirements (with a value of about $\$ 1.5$ billion). Oil and petroleum product imports are a state monopoly (of Pakistan State Oil). Refined products are handed over for distribution to essentially three companies - one state owned and two foreign owned - (Pakistan State Oil, Caltex and Shel1). Similarly, gas production in Pakistan (meeting 50 per cent of national energy requirements) is largely generated by one major field (Sui)which is foreign owned and distributed by two state owned companies in the process of being privatised to strategic foreign buyers. The entire energy sector is essentially a large cartel. Regulation of both the petroleum and gas sectors is not transparent. There are therefore serious questions which relate to the privatisation strategy of the government in the absence of adequate regulatory capacity and it may make a great deal of sense to privatise it in 'many parts' as recommended for the electricity and telephone sectors.

In the roads sector, the Pakistan Highways Authorities are encouraging a BOT (Build, Operate, Transfer) approach to a large number of construction companies, both domestic and foreign with regulated but generous tariffs. This seems to be a sensible approach - being in line with the proposals made above - and should be encouraged. 


\section{Competition Policy and Democracy}

Prudent competition policy and de-regulation go hand in hand with democracy and mutually re-inforce each other. In Pakistan, competition policy is appropriately focusing in the case of traded sectors on increasing competition through more liberal trade policies and reducing and eliminating tariffs. Some recently privatised industrial sectors such as cement, where transportation costs are high, have formed cartels and a regulatory authority for the private industrial sector - The Monopoly Control Authority - is struggling to deal with them. However, these problems are manageable in the long term as regulatory capacity is developed. It is in the non-traded sectors, notably the human resource sectors like education and public administration, that competition policy has failed and no solutions are being sought or are in sight. Finally, the infrastructure and energy sectors raise questions of regulation both in their public and currently proposed private sector modes.

The Regulatory Authority which presently exists in Pakistan to deal with these issues is the Monopoly Control Authority established in 1971 under the Monopolies and Restrictive Trade Practices (Control and Prevention) Ordinance 1970 promulgated by the second military government (1968-71). This was a response to the public concern about the increased concentration of economic power in industry and finance during the first military government of F.M. Ayub Khan (1958-1968). The Ordinance (Law) regulates the following situations: (i) Undue concentration of economic power; (ii) Unreasonable monopoly power and (iii) Unreasonably restrictive trade practices. Regulation of "Undue Concentration of Economic Power" can be ordered through disinvestment of share capital to the general public while "Restrictive Trade Practices" (including price fixing by a monopoly or cartel) can be ordered to be corrected. While this Law is a good starting point it has not been applied or used in the last few years to any significant effect (unlike India where it is used fairly effectively). It is also restricted to the private industrial sector. The Law needs to be extended to all sectors and to public and semi-public enterprises. The Monopoly Control Authority needs to be strengthened to ensure that competition is encouraged in every sector of the economy.

Finally, it should be noted that the first Pakistani democratic response to extreme concentration of economic power and monopoly situations was that of nationalisation. This was probably in line with the pro-state economic philosophy of the times and did not recognise the fact that state monopolies are both inefficient and encourage rent-seeking by bureaucrats. However, the current emerging concentration in the industrial sectors and the potential inherent for extreme concentration as a result of the planned privatisation process, particularly in the infrastructure sectors, is a cause for concern. While the current democratic response and economic thinking in Pakistan is more 
78 The Lahore Journal of Economics, Vol.1, No.1

enlightened and in line with current economic philosophy to use more sophisticated indirect policy instruments to encourage competition, unless the democratic governments in power encourage competition, regulate monopolies, and by any means do not create new monopoly situations (even for progressive, big multinationals), the next democratic response may be emotional. It could possibly lead to re-nationalisation or at the very least the slow down of desired privatisation in many sectors of the economy. 
Shabid Amjad Chaudhry 79

Annexure -I-I

\section{Sectoral Growth Rates}

\begin{tabular}{lccccc}
\hline & $\begin{array}{c}\text { Democracy } \\
\mathbf{1 9 4 7 - 5 8}\end{array}$ & $\begin{array}{c}\text { Dictatorship } \\
\mathbf{1 9 5 8 - 7 1}\end{array}$ & $\begin{array}{c}\text { Democracy } \\
\mathbf{1 9 7 2 - 7 8}\end{array}$ & $\begin{array}{c}\text { Dictatorship } \\
\mathbf{1 9 7 8 - 8 8}\end{array}$ & $\begin{array}{c}\text { Democracy } \\
\mathbf{1 9 8 8 - 9 5}\end{array}$ \\
\hline G.D.P. & 3.1 & 5.2 & 5.8 & 6.6 & 4.8 \\
Public & 2.7 & 5.9 & 12.7 & 6.5 & 3.3 \\
Administration & & & & & \\
Agriculture & 2.4 & 3.9 & 2.2 & 3.9 & 3.5 \\
Industry LS & 18.0 & 10.8 & 3.7 & 9.0 & 4.8 \\
Finance \& & 8.6 & 13.0 & 11.9 & 7.1 & 4.1 \\
Banking & & & & & \\
Electricity \& & 9.9 & 20.9 & 8.0 & 8.9 & 9.5 \\
Gas & & & & & \\
Transport \& & 4.7 & 5.1 & 6.9 & 7.6 & 4.1 \\
Communication & & & & & \\
\hline
\end{tabular}

Source: Pakistan Economic Survey, Statistical Supplement 1993-94. 